\title{
AKTIVITAS ANTIBAKTERI DAN ANALISIS KLT-BIOAUTOGRAFI DARI FRAKSI DAUN MENGKUDU (Morinda citrifolia L.)
}

\author{
Aprilia Pratiwi Aslah ${ }^{1)}$, Widya Astuty Lolo ${ }^{1)}$, Imam Jayanto \\ ${ }^{1)}$ Program Studi Farmasi FMIPA UNSRAT Manado, 95115
}

\begin{abstract}
Noni is a nutritious plant because it has several ingredients that are important for health. Antibacterial components in noni leaves include glycosides, acubins, saponins and flavonoids. The purpose of this study was to determine the fraction of the extract of noni leaf ethanol whether it has an antibacterial effect and know the class of compounds indentifed as having antibacterial activity after TLC-Bioautografi testing was carried out. The samples were extracted using maceration method with $96 \%$ ethanol solvent and fractionation using liquidliquid fractionation method with methanol, ethyl acetat and n-hexane solvents. Antibacterial activity testing was carried out with concentration variants of 20\%, 30\% and 40\% with agar diffusion method (Kirby and Bauer). The results showed that methanol fraction, ethyl acetat fraction and Noni hexane leaf fraction effectively inhibited Staphylococcus aureus and Escherichia coli bacteria. The largest fraction of inhibiting zone was the concentration of $40 \%$ methanol which was categorized as strong. TLC monitoring was carried out using the mobile phase of chloroform : n-hexane (2:1). Antibacterial activity testing carried out by contact bioautography method showed that there were spots on the TLC choromatogram, which produced inhibitory zones. Characteristics of blotches were performed with $\mathrm{AlCl}_{3}$ spotting and it was thought that the spots were flavonoids.
\end{abstract}

Keywords : Noni, Antibacterial, Staphylococcus aureus, Escherichia coli, TLC-Bioautografi.

\begin{abstract}
ABSTRAK
Mengkudu merupakan tanaman yang berkhasiat karena mempunyai beberapa kandungan senyawa yang penting bagi kesehatan tubuh. Komponen yang berkhasiat antibakteri dalam daun mengkudu antara lain adalah glikosida, acubin, saponin dan flavonoid. Tujuan dari penelitian ini adalah untuk mengetahui fraksi dari esktrak etanol daun mengkudu apakah memiliki efek antibakteri dan mengetahui golongan senyawa yang teridentifikasi memiliki aktivitas antibakteri setelah dilakukan pengujian KLT-Bioautografi. Sampel diekstraksi menggunakan metode maserasi dengan pelarut etanol $96 \%$ dan fraksinasi dengan metode fraksinasi cair-cair dengan pelarut metanol, etil asetat dan n-heksan. Pengujian aktivitas antibakteri dilakukan dengan varian konsentrasi 20\%, 30\% dan $40 \%$ dengan metode difusi agar (Kirby dan Bauer). Hasil penelitian menunjukan bahwa fraksi metanol, fraksi etil asetat dan fraksi n-heksan daun Mengkudu efektif menghambat bakteri staphylococcus aureus dan Escherichia coli. fraksi yang paling besar zona hambatnya yaitu fraksi metanol konsentrasi $30 \%$ yang dikategorikan kuat, dilakukan pemantauan KLT menggunakan fase gerak kloroform : n-heksan (2:1). Pengujian aktivitas antibakteri dilakukan dengan metode bioautografi kontak hasilnya menunjukkan terdapat bercak pada kromatogram KLT yang menghasilkan zona hambat. Karakteristik bercak dilakukan dengan penampak bercak $\mathrm{AlCl}_{3}$ dan diduga bahwa bercak tersebut Flavonoid.
\end{abstract}

Kata kunci : Mengkudu, Antibakteri, Staphylococcus aureus, Escherichia coli, KLT-Bioautografi 


\section{PENDAHULUAN}

Penggunaan bahan alami sebagai zat hambat mikroorganisme adalah langkah kembali ke alam untuk memanfaatkan bahan alami. Senyawa dalam tumbuhan, mengharuskan kita untuk mengetahui senyawa kimia yang mampu memberikan efek terapi.

Mengkudu merupakan tanaman khas Indonesia yang telah dimanfaatkan untuk berbagai pengobatan. Daun mengkudu mengandung senyawa kimia yang sangat bermanfaat bagi manusia dan banyak mengandung protein, zat kapur, zat besi, karoten, askorbin, alkaloid, saponin, flavonoid, polifenol, alizarin, antraquinon, scolopetin, acubin, imunostimulan (Sastrohamidjojo, 1996). Sebagai salah satu spesies tanaman obat daun mengkudu telah diuji klinis menyangkut kandungan kimia, khasiat dan keamanan penggunannya (Rukmana, 2010).

Hasil penelitian Diassanti (2011), menyatakan bahwa daun mengkudu memiliki kandungan saponin, flavonoid, polifenol, tanin, dantriterpen. Zat aktif tersebut dapat menghambat pertumbuhan terhadap bakteri Staphylococcus aureus dan Escherichia coli. Hasil penelitian Djauharia (2003), telah membuktikan bahwa pada daunmengkudu terdapat senyawa aktif yang berfungsi sebagai zat antibakteri.

Penggunaan ekstrak daun mengkudu juga telah dilakukan oleh Widiana (2011), hasilnya ekstrak tersebut juga berpengaruh terhadap pertumbuhan Escherichia coli dan Salmonella sp. Penelitian yang dilakukan oleh Jayaraman (2008) menunjukkan bahwa ekstrak mengkudu memiliki efek anti jamur terhadap Candida albicans, Tricophyton mentagrophytes, Penicillium sp., Rhizopus, Aspergilus plavus, dll. Selain itu juga memiliki efek anti bakteri terhadap Pseudomonas aeruginosa, Proteus morganii, Staphylococcus aureus, Bacillus subtilis dan Escherichia coli, Salmonella sp. dan Shigella sp.

Berdasarkan penelitian adanya aktivitas antibakteri dan kandungan kimia daun mengkudu yang memiliki senyawa bioaktif alami. Hal ini perlu dilakukan penelitian lanjutan terhadap daun mengkudu dengan menguji aktivitas antibakteri dan analisis KLT-Bioautografi dari senyawa aktif tersebut.

\section{METODOLOGI PENELITIAN}

\section{Waktu dan Tempat}

\section{Penelitian}

Penelitian ini dilaksanakan pada bulan Februari sampai April 2019. Tempat pengambilan sampel dilakukan di desa Amongena 1, Kecamatan Langoan Timur, Kabupaten Minahasa. Preparasi sampel dan pengamatan dilakukan di Laboratorium Penelitian Farmasi Lanjutan, Program Studi Farmasi, Fakultas Matematika dan Ilmu Pengetahuan Alam, Universitas Sam Ratulangi Manado.

\section{Bentuk Penelitian}

Penelitian ini dilakukan dengan menggunakan metode eksperimental yang artinya penelitian ini dilakukan untuk mengetahui akibat yang ditimbulkan dari suatu perlakuan yang diberikan secara sengaja oleh peneliti. 


\section{Alat dan Bahan}

a. Alat

Alat yang digunakan dalam penelitian ini yaitu jas lab, masker, sarung tangan, gunting, alat maserasi, autoklaf, cawan petri (Normax), cawan porselin, chamber, gelas Erlenmeyer (pyrex), gelas kimia (pyrex), gelas ukur (pyrex), tabung reaksi, rak tabung reaksi, corong pisah, pinset, pembakar spritus, inkubator, lemari pendingin, blender, batang pengaduk, oven, lampu spiritus, lampu UV $254 \mathrm{~nm}$ dan $366 \mathrm{~nm}$, Laminary Air Flow(N Biotek), aluminium foil, micropipet, pipet tetes, spatula, penangas air, rotary evaporator, vial, jangka sorong, jarum ose, lempeng KLT, pipa kapiler.

b. Bahan

Bahan yang digunakan adalah sampel ekstrak daun mengkudu (Morinda citrifolia L), akudes, bakteri uji Escherchia coli (gram negatif) dan Staphylococcus aureus (gram positif), Medium Nutrient Agar (NA), Kloramfenikol paper disk, cakram (paper disk), n-heksan, etil asetat, etanol, label, tissue, aluminium foil, kertas saring, kapas, larutan $\mathrm{H}_{2} \mathrm{~S}_{4} 1 \%$, Larutan $\mathrm{BaCl}_{2}+2 \mathrm{H}_{2} \mathrm{O}$ $1,75 \%$, pereaksi $\mathrm{AlCl}_{3}$

\section{Prosedur Penelitian}

\section{Ekstraksi}

Sampel diekstraksi dengan metode maserasi menggunakan pelarut etanol $96 \%$. Serbuk ditimbang sebanyak 600 g dan dimasukkan kedalam wadah maserasi kemudian ditambahkan pelarut etanol $96 \%$ sebanyak 1,8 L dan ditutup dengan aluminium foil dan dibiarkan selama 3 hari sambil sesekali didaduk. Setelah 3 hari, sampel yang direndam disaring dengan menggunakan kertas saring menghasilkan filtrat 1 dan debris 1 . Kemudian dilakukan remaserasi selama 2 hari dengan merendam debris 1 dengan etanol 96\% sebanyak 1,2 L. kemudian Sampel tersebut disaring menggunakan kertas saring menghasilkan filtrat 2 dan debris 2 . Filtrat 1 dan 2 dicampur menjadi satu kemudian disaring, lalu hasil penyaringan dipekatkan menggunakan oven sehingga diperoleh ekstrak kental sebanyak 36 g, kemudian ekstrak disimpan dalam wadah, sebelum digunakan untuk pengujian.

\section{Fraksinasi}

Fraksinasi sampel dilakukan dengan metode fraksinasi cair-cair menggunakan corong pisah. Dengan menggunakan tiga pelarutyaitu n-heksan, etil asetat, dan metanol. Sebanyak 10,00 g ekstrak kental dimasukkan kedalam Erlenmeyer dan di larutkan dengan metanol sebanyak $100 \mathrm{~mL}$. Setelah sampel larut, sampel dimasukkan ke dalam corong pisah dan ditambahkan pelarut n-heksan sebanyak 100 mL. Sampel kemudian dikocok berulangkali dalam corong pisah hingga homogen. Sampel dibiarkan hingga membentuk dua lapisan yaitu lapisan metanol dan n-heksan. Masingmasing kedua lapisan metanol dan nheksan ditampung dalam wadah yang berbeda. Lapisan n-heksan selanjutnya dipekatkan menggunakan oven hingga kering lalu ditimbang dengan timbangan analitik dan diperoleh fraksinat.

Selanjutnya lapisan metanol dimasukkan kedalam corong pisah dan ditambahkan pelarut etil asetat sebanyak 100 mL. Sampel dibiarkan membentuk dua 
lapisan yaitu lapisan metanol dan lapisan etil asetat. Masing-masing kedua lapisan metanol dan etil asetat ditampung dalam wadah yang berbeda. Lapisan etil asetat dan metanol selanjutnya dipekatkan menggunakan oven hingga kering lalu ditimbang dengan timbangan analitik dan diperoleh fraksinat.

\section{Sterilisasi dan Pembuatan Media Sterilisasi Alat}

Alat-alat gelas yang digunakan dalam penelitian ini disterilkan terlebih dahulu dengan menggunakan autoklaf pada suhu $121^{\circ} \mathrm{C}$ selama 15 menit. Pinset, jarum ose, dan $L$ glass dipijarkan diatas api bunsen dan media disterilkan di autoklaf pada suhu $121^{0} \mathrm{C}$ selama 15 menit.

\section{Pembuatan Media Nutrient Agar}

Ditimbang sebanyak 10,08 g nutrient agar kemudian dilarutkan dengan aquades sampai $120 \mathrm{~mL}$, diaduk sampai homogen. Media yang telah homogen kemudian disterilkan dengan menggunakan autoklaf pada suhu $121^{\circ} \mathrm{C}$ selama 15 menit dan dibiarkan media sampai cukup dingin. Selanjutmya media nutrient agar yang masih cair dituang sebanyak $18 \mathrm{~mL}$ ke dalam cawan petri dibiarkan hingga memadat.

\section{Pembuatan Media Agar Miring}

Pembuatan agar miring dilakukan dengan memasukkan $10 \mathrm{~mL}$ media yang telah disterilkan dalam tabung reaksi kemudian disumbat dengan kapas steril dan dimiringkan sekitar $45^{\circ}$. Diidiamkan hingga memadat pada suhu ruangan. Media agar miring digunakan sebagai peremajaan bakteri.

\section{Pengujian Aktivitas Antibakteri Pembuatan Larutan standar Mc Farland 0,5}

Larutan $\mathrm{H}_{2} \mathrm{~S} 04 \quad 1 \%$ sebanyak 9,95

$\mathrm{mL}$ dicampurkan dengan larutan $\mathrm{BaCl}_{2 .} .2 \mathrm{H}_{2} \mathrm{O} \quad 1,75 \%$ sebanyak $0,05 \% \mathrm{~mL}$ dalam Erlenmeyer. Kemudian dikocok sampai terbentuk larutan yang keruh sebagai standar kekeruhan suspensi mikroba uji.

\section{Pembuatan Suspensi Bakteri Uji}

Bakteri uji yaitu Staphylococcus aureus dan Escherichia coli yang telah diinokulasi diambil kurang lebih 1 ose kemudian disuspensikan ke dalam tabung yang berisi $10 \mathrm{~mL}$ larutan $\mathrm{NaCL} 0,9 \%$. Selanjutnya dibandingkan dengan standar kekeruhan larutan Mc Farland 0,5.

\section{Kontrol Positif dan Kontrol Negatif}

Kontrol Positif untuk pengujian aktivitas antibakteri ini menggunakan Kloramfenikol paper disc dan untuk kontrol negatif menggunakan akuades

\section{Pembuatan Larutan Uji}

Dibuat larutan stok dengan konsentrasi 100\% dengan cara ditimbang $1 \mathrm{~g}$ fraksi metanol, fraksi etil asetat dan fraksi nheksan kemudian masing-masing dilarutkan dengan akuades hingga $1 \mathrm{~mL}$. Larutan uji fraksi metanol, fraksi etil asetat, fraksi nheksan 20\%, 30\% dan 40\% dibuat dengan cara mengambil masing-masing sebanyak 0,2 mL, 0,3 mL, 0,4 mL untuk setiap konsentrasinya dan dicukupkan volumenya dengan akuades hingga $1 \mathrm{~mL}$. 


\section{Pengujian Aktivitas Antibakteri}

Pada penelitian ini digunakan metode difusi agar (disc diffusion Kriby and Bauer). Aktivitas penghambatan diuji pada bakteri Staphylococcus aureus ATCC 25923 dan Escherichia coli ATCC 25922. Digunakan kertas cakram yang berukuran 6 mm untuk pengujian aktivitas antibakteri. Suspensi bakteri kemudian diinokulasikan ke dalam media dengan menggunakan $L$ glass dan dihomogenkan. Sampel yang telah ditentukan konsentrasinya 20\%, 30\%, dan $40 \%$ selanjutnya ditotolkan pada masingmasing kertas cakram. Masing-masing cawan petri diberi label sesuai dengan komponen pengujian. Kertas cakram yang terdiri dari kontrol positif, kontrol negatif dan kertas cakram yang telah ditotolkan larutan uji diletakkan dalam cawan petri dengan menggunakan pinset lalu diinkubasi selama 1 x 24 jam.

\section{Pengamatan dan Pengukuran Zona Bening}

Pengamatan dilakukan setelah 1 x 24 jam masa inkubasi. Zona bening yang terbentuk sekitaran cakram menunjukkan kepekaan bakteri terhadap antibiotik atau larutan uji antibakteri sebagai bahan uji. Diameter zona bening diukur dalam satuan milimeter (mm) menggunakan jangka sorong. Kemudian zona bening yang telah diukur dibandingkan berdasarkan pedoman.

\section{Pengujian Fraksi Teraktif dengan Metode KLT-Bioautografi}

Fraksi yang memiliki zona hambat yang paling besar dilakukan pemantauan KLT. Kemudian hasil pemantauan KLT dilakukan pengujian aktivitas antibakteri dengan metode KLT-Bioautografi.

\section{Persiapan Plat KLT}

Pemisahan senyawa dari fraksi teraktif dilakukan dengan menggunakan plat silika sebagai fase diam dengan ukuran $1 \mathrm{x}$ $10 \mathrm{~cm}$. Selanjutnya diberi tanda garis pada tepi atas dan bawah plat dengan jarak $1 \mathrm{~cm}$ untuk menunjukkan posisi awal totolan dan tepi atas sebagai tanda batas dari proses elusi. Selanjutnya plat diaktifkan dengan cara dipanaskan pada suhu $105^{\circ} \mathrm{C}$ selama 10 menit untuk menghilangkan kadar air yang terdapat pada plat KLT.

\section{Persiapan Fase Gerak (Eluen)}

Eluen yang digunakan sebagai fase gerak yaitu kloroform : n-heksan (2:1). Eluen yang berada dalam chamber dijenuhkan terlebih dahulu dengan menggunakan kertas saring selama 10 menit, agar menyamakan tekanan uap pada seluruh bagian bejana.

\section{Penotolan Sampel Fraksi}

Fraksi metanol dengan konsentrasi $30 \%$ ditotolkan pada tiga lempeng yang berbeda dengan jarak $1 \mathrm{~cm}$ dari tepi bawah plat dengan menggunakan pipa kapiler. Kemudian dikeringkan dengan cara dianginanginkan. Lempeng pertama diamati dengan lampu UV 254 nm dan lampu UV 366 nm. Lempeng kedua disemprotkan reagen Aluminium Klorida $\left(\mathrm{AlCl}_{3}\right)$ untuk melihat senyawa flavonoid dan lempeng ke tiga digunakan untuk uji bioautografi.

\section{Uji Bioautografi}

Sebanyak $10 \mathrm{ml}$ medium nutrient agar dituangkan ke dalam cawan petri secara aseptis dan dibiarkan sampai media memadat kemudian sebanyak $20 \mu \mathrm{l}$ mikroba 
uji diinokulasi ke dalam media. Kromatogram hasil pemisahan senyawa secara KLT kemudian diletakkan di atas permukaan medium yang memadat. Didiamkan selama 30 menit dilemari pendingin, kemudian lempeng (kromatogram) diangkat dan dikeluarkan dari medium. Selanjutnya diinkubasi selama 1 x 24 jam pada suhu $37^{0} \mathrm{C}$ untuk pengamatan hasil.

\section{HASIL DAN PEMBAHASAN Ekstraksi dan Fraksinasi}

Sampel daun Mengkudu dibersihkan dari kotoran yang menempel disekitarnya. Kemudian dikeringkandi tempat yang tidak terkena sinar matahari secaralangsung untuk mencegah adanya senyawa kimia yang rusak akibat terkena sinarmatahari langsung.Sampel daun Mengkudu selanjutnya diekstraksi dengan metode maserasi yang diperkirakan tidak dapat merusak senyawa kimia yang terdapat dalam sampel. Maserasi dilakukan dengan menggunakan pelarut etanol $96 \%$ dan dalam ruangan tertutup untuk menghindari pengaruh cahaya (sinar matahari) terhadap stabilitas senyawa-senyawa yang akan diambil.

Perendaman sampel dalam maserasi dapat membuat dinding sel dari sampel pecah dan membuat senyawa-senyawa yang ada dalam sampel yang terdapat dalam sitoplasma akan tertarik oleh pelarut. Dinding sel pecah di karenakan adanya perbedaan konsentrasi di dalam dan di luar sel. Konsentrasi di luar sel lebih tinggi dibandingkan konsentrasi di dalam sel yang rendah sehingga dinding sel pecah karena tidak bisa menahan tekanan dari perbedaan konsentrasi (Harbone,1996). Sampel yang telah di maserasi selama 3 hari kemudian dilakukan remaserasi kembali dengan penggantian pelarut sebanyak dua kali dengan pelarut etanol. Maserasi lebih efisien dilakukan berulangkali dibandingkan hanya sekali (Khopkar, 2008 dalam Mujipradhana, 2018).

Hasil maserasi kemudian disaring dan dilakukan pemekatan. Pemekatandilakukan dengan bantuan oven dengan suhu $40{ }^{0} \mathrm{C}$. Zat yang bersifat termolabil harus dipekatkan dengan suhu dibawah titik didihnya. Sehingga kandungan senyawa metabolit sekunder yang terkandung di dalam pelarut tidak mengalami kerusakan oleh suhu yang tinggi (Hermansah et al., 2015).

Pada penelitian ini fraksinasi dilakukan dengan metode fraksinasi cair-cair yaitu metode pemisahan dengan menggunakan dua cairan yang tidak saling bercampur. Pelarut dengan massa jenis lebih tinggi berada di lapisan bawah sedangkan pelarut dengan massa jenis lebih kecil berada di lapisan atas. Fraksi yang diperoleh di uapkan menggunakan oven dan digunakan untuk uji aktivitas antibakteri.

\section{Uji Aktivitas Antibakteri Mengkudu}

Pengujian aktivitas antibakteri dari fraksi metanol, fraksi etil asetat, dan fraksi n-heksan pada bakteri uji Staphylococcus aureusdan Escherichia coli menggunakan metode difusi agar (difusi Kirby dan Bauer). Bakteri uji yang digunakan adalah Staphylococcus aureus dan Escherichia coli. Penggunaan bakteri ini bertujuan untuk mengetahui apakah fraksi dari daun mengkudu memiliki aktivitas antibakteri 
serta untuk mengetahui apakah fraksi dari mengkudu bersifat spektrum luas.

Dalam pengujian yang telah dilakukan hasil yang didapat yaitu adanya zona hambat disekeliling cakram yang ditandai dengan adanya zona bening. Hal ini menunjukan adanya kepekaan bakteri uji terhadap fraksi dari Mengkudu dan antibiotik yang digunakan sebagai kontrol positif. Pengamatan dilakukan setelah diinkubasi pada suhu $37^{0} \mathrm{C}$ selama 1 x 24 jam dengan pengulangan sebanyak tiga kali pada masing-masing bakteri uji, pengulangan yang dilakukan untuk lebih mengakuratkan hasil yang diperoleh.

Dalam pengujian ini dilakukan pada variasi konsentrasi 20\%, 30\% dan 40\%, pengujian antibakteri menggunakan variasi konsentrasi ini dilakukan untuk mengetahui pengaruh dari pemberian konsentrasi ekstrak yang berbeda terhadap bakteri uji. Hasil pengukuran rata-rata diameter daya antibakteri dari fraksi metanol, fraksi etil asetat dan fraksi n-heksan terhadap bakteri uji Staphylococcusaureus dan Escherichia coli dapat dilihat pada Tabel 1 dan Tabel 2.

Tabel 1. Hasil rata-rata diameter zona hambat terhadap bakteri uji Staphylococcus aureus .

\begin{tabular}{|c|c|c|c|}
\hline \multicolumn{4}{|c|}{ Rata-rata diameter (mm) pada tiga konsetrasi } \\
\hline & $20 \%$ & $30 \%$ & $40 \%$ \\
\hline $\begin{array}{l}\text { Fraksi } \\
\text { metanol }\end{array}$ & 7,83 & 9,75 & 11,58 \\
\hline $\begin{array}{l}\text { Fraksi etil } \\
\text { asetat }\end{array}$ & 6,83 & 8,66 & 9,66 \\
\hline $\begin{array}{ll}\text { Fraksi } & n- \\
\text { heksan } & \end{array}$ & 7,33 & 8,31 & 8.75 \\
\hline $\begin{array}{l}\text { Kontrol } \\
\text { positif }\end{array}$ & 16,86 & 17,16 & 17,16 \\
\hline $\begin{array}{l}\text { Kontrol } \\
\text { negatif }\end{array}$ & 0 & 0 & 0 \\
\hline
\end{tabular}

Tabel 2. Hasil rata-rata diameter zona hambat terhadap bakteri uji Escherichia coli

\begin{tabular}{|c|c|c|c|}
\hline \multicolumn{4}{|c|}{ Rata-rata diameter (mm) pada tiga konsetrasi } \\
\hline & $20 \%$ & $30 \%$ & $40 \%$ \\
\hline $\begin{array}{l}\text { Fraksi } \\
\text { metanol }\end{array}$ & 8,67 & 10,66 & 11,75 \\
\hline $\begin{array}{l}\text { Fraksi etil } \\
\text { asetat }\end{array}$ & 8,33 & 10,16 & 10,41 \\
\hline $\begin{array}{l}\text { Fraksi n- } \\
\text { heksan }\end{array}$ & 9,33 & 9,66 & 10,08 \\
\hline $\begin{array}{l}\text { Kontrol } \\
\text { positif }\end{array}$ & 17,66 & 18 & 17,86 \\
\hline $\begin{array}{l}\text { Kontrol } \\
\text { negatif }\end{array}$ & 0 & 0 & 0 \\
\hline
\end{tabular}

Pada penelitian ini fraksi n-heksan, fraksi etil asetat dan fraksi metanol lebih efektif menghambat pertumbuhan bakteri Escherichia coli dibandingkan bakteri Staphylococcus aureus. Respon yang berbeda dari dua bakteri ini terhadap senyawa antibakteri disebabkan karena adanya perbedaan komposisi dan struktur dinding sel.

Menurut Radji (2012), perbedaan struktur dinding sel bakteri Gram negatif dan bakteri Gram positif mempengaruhi sensitivitas terhadap bakteri. Dinding sel bakteri Gram positif terdiri atas sekitar 40 lapisan peptidoglikan sehingga peptidoglikan mencapai $70 \%$ dari massa kering dinding sel. Hal ini menyebabkan dinding sel menjadi tebal dan kaku. Berbeda dengan bakteri gram negatif yang memiliki dinding sel peptidoglikan hanya sekitar $10 \%$ dari massa kering dinding sel, sehingga menyebabkan dinding sel bakteri Gram negatif lebih tipis (Pelczar, 1988). Bakteri Gram negatif mempunyai kandungan lipid yang banyak serta memiliki protein porin yang berperan sebagai saluran masuknya zat aktif ke dalam sel bakteri. Masuknya zat aktif ini merusak aktivitas enzim dalam sel dan menyebabkan kerusakan sel. Kadar lipid yang tinggi didalam sel akan meningkatkan 
permeabilitas zat aktif kedalam sel (Ardila, et al., 2013).

Hasil yang diperoleh dari pengukuran rata-rata zona hambat diketahui bahwa fraksi metanol dan fraksi etil asetat dengan konsentrasi $30 \%$ dan $40 \%$ terhadap bakteri uji Escherichia coli digolongkan kategori kuat. Fraksi metanol dan fraksi etil asetat dengan konsentrasi $20 \%$ digolongkan kategori sedang. Untuk fraksi n-heksan konsentrasi $40 \%$ digolongkan kategori kuat dan fraksi n-heksan $20 \%$ dan $30 \%$ digolongkan kategori sedang. Untuk bakteri uji Staphylococcus aureus ditunjukkan hanya fraksi metanol dengan konsentrasi $40 \%$ digolongkan kategori kuat. Sedangkan untuk fraksi yang lainnya dikategorikan sedang. Dilihat dari hasil yang ada menunjukkan ketiga fraksi bersifat spektrum luas, artinya kandungan senyawa yang terkandung memiliki antibakteri terhadap bakteri Gram positif maupun bakteri Gram negatif.

Diameter zona hambat yang ditunjukkan pada fraksi metanol lebih besar dari pada fraksi etil asetat dan fraksi nheksan. Hal ini disebabkan karena daun mengkudu mengandung senyawa antibakteri yang bersifat polar seperti flavonoid, glikosida dan tannin. Sehingga fraksi metanol lebih mudah menarik senyawa polar yang terkandung dalam daun mengkudu (Sitepu, 2012).

Kemampuan suatu bahan antibakteri dalam meniadakan kemampuan hidup organisme tergantung pada konsentrasi bahan yang digunakan (Schlegel, 1994). Berdasarkan hasil uji aktivitas antibakteri pada Tabel 1 dan Tabel 2, menunjukkan diameter zona hambat pertumbuhan bakteri
Staphylococcus aureus dan Escherichia coli yang terbentuk pada konsentrasi $40 \%$ lebih besar dibandingkan konsentrasi ekstrak $20 \%$ dan 30\%. Menurut Ajizah (2004), bahwa semakin besar konsentrasi suatu bahan antibakteri yang diberikan maka aktivitas antibakteri semakin besar pula. Semakin tinggi konsentrasi ekstrak maka kandungan senyawa fitokimia berkhasiat antibakteri juga akan semakin banyak.

Kriteria kekuatan daya hambat antibakteri yaitu diameter zona hambat $<5$ $\mathrm{mm}$ dikategorikan lemah, zona hambat 5-10 $\mathrm{mm}$ dikategorikan sedang, zona hambat 10$20 \mathrm{~mm}$ dikategorikan kuat dan > $20 \mathrm{~mm}$ dikategorikan sangat kuat (Davis dan Stout 1971).

\section{Pengujian Fraksi Teraktif Dengan Metode KLT-Bioautografi}

Pengujian secara KLT-Biautografi dilakukan terhadap fraksi metanol secara kromatografi lapis tipis. Pengujian ini bertujuan untuk mengetahui kandungan senyawa yang terdapat dalam fraksi metanol daun Mengkudu pada kromatogram dengan melihat zona hambat yang terbentuk pada media agar. Pengujian ini dilakukan dengan menggunakan lempeng KLT yang telah diberi tanda batas bagian bawah dan bagian atas lempeng sebagai tanda batas elusi. Jarak elusi yang dibuat adalah $8 \mathrm{~cm}$ dengan harapan jarak ini cukup untuk memisahkan senyawa-senyawa yang akan terelusi pada plat KLT. Lempeng KLT yang akan digunakan sebelumnya dipanaskan terlebih dahulu dengan suhu $105^{\circ} \mathrm{C}$ selama 10 menit yang bertujuan untuk menghilangkan kadar air yang terdapat dalam lempeng (Sastrohamidjojo, 1991). 
Pemisahan senyawa fraksi metanol menggunakan perbandingan eluen kloroform : n-heksan $(2: 1)$. Pemilihan eluen ini didasarkan pada hasil orientasi eluen yang telah dilakukan yang dimana pada eluen ini menghasilkan pemisahan terbaik dengan jumlah noda terbanyak setelah dideteksi bercak pada lampu UV $254 \mathrm{~nm}$ dan $366 \mathrm{~nm}$.

Menurut Saifudin (2014), karakterisitik eluen yang baik ditandai dengan banyaknya spot yang muncul, spot yang terbentuk tidak berekor, dan jarak antara spot satu dengan spot lainnya jelas.

Selanjutnya dilakulan pengujian bioautografi yang merupakan pengujian lanjutan. Pada penelitian ini digunakan metode bioautografi kontak, metode ini menjadi pilihan karena mempertimbangkan kesederhanaan dalam pengerjaan, dan hasilnya lebih jelas terlihat. Lempeng yang telah dielusi dikontakkan dipermukaan media padat berisikan masing-masing inokulasi bakteri Staphylococcus aureus dan Escherichia coli selama 30 menit. Lempeng kemudian diangkat dari media dan media agar diinkubasi selama 1 x 24 jam, sehingga diperoleh zona hambatan dipermukaan media bekas lempeng dikontakkan yang menunjukkan lokasi dari senyawa yang bertanggung jawab terhadap aktivitas antibakteri.

Dari hasil KLT-Bioautografi menunjukkan bahwa terdapat zona hambat pada kedua bakteri uji. Pada bakteri Escherichia coli zona hambat terbesar yang muncul terdapat pada bercak dengan nilai $\mathrm{Rf}$ 0,00 sedangkan pada bakteri Staphylococcus aureus menunjukkan adanya zona hambat terbesar ditunjukkan pada bercak dengan nilai $\operatorname{Rf} 0,38$.

\section{Identifikasi Senyawa Aktif}

Untuk mengetahui senyawa yang diduga memiliki aktivitas antibakteri terhadap bakteri Staphylococcus aureus dan Escherichia coli, maka dilakukan identifikasi senyawa. Menurut Rukmana (2010) senyawa dari daun mengkudu yang memiliki aktivitas antibakteri antara lain adalah flavonoid, glikosida dan saponin. Flavonoid merupakan senyawa polifenol yang mempunyai fungsi sebagai senyawa antibakteri dengan cara mengganggu intergritas membran sel bakteri (Wijayati, et al., 2014).

Dari hasil pengamatan yang dilakukan dengan menggunakan penampak bercak Aluminium Klorida $\left(\mathrm{AlCl}_{3}\right)$ terlihat terjadi perubahan warna pada bercak pada nilai $\operatorname{Rf} 0,00,0,31,0,38,0,62$ menjadi warna kuning. Menurut penelitian yang dilakukan Irwan (2017), menyatakan bahwa penyemprotan dengan pereaksi $\mathrm{AlCl}_{3}$ ditandai dengan warna noda menjadi kuning sehingga menunjukkan bahwa senyawa tersebut positif flavonoid. Menurut Markham (1998), flavonoid merupakan senyawa polar maka umumnya flavonoid cukup larut dalam pelarut polar seperti etanol, metanol, butanol, aseton dan air. Adanya gula yang terikat pada flavonoid cenderung menyebabkan flavonoid mudah larut dalam pelarut polar. 


\section{KESIMPULAN}

Berdasarkan hasil penelitian yang dilakukan dapat disimpulkan bahwa :

1. Fraksi n-heksan, fraksi etil asetat dan fraksi metanol memiliki aktivitas antibakteri terhadap pertumbuhan bakteri Staphylococcus aureus dan Escherichia coli dengan zona hambat paling besar pada konsentrasi $40 \%$.

2. Senyawa aktif daun Mengudu (Morinda citrifolia L.) yang berperan sebagai antibakteri pada fraksi metanol diduga positif mengandung senyawa Flavanoid.

\section{SARAN}

Sebaiknya dilakukan penelitian lebih lanjut untuk uji KLT-Bioautografi dengan menggunakan metode KLT-Bioautografi langsung.

\section{DAFTAR PUSTAKA}

Ajizah, A. 2004. Sensitivitas Salmonellan thypimurium Terhadap Ekstrak Daun (Psidium guajaya L). Jurnal Bioscientiae.7(1) : 31-38.

Ardila, R., Nurmiati., Agustien A. 2013. Uji Antimikroba Curcuma spp. Terhadap Pertumbuhan Candida albicans, Staphylococcus aureus dan Escherichia coli. Jurnal Biologi UNAND. 2(1) : 1-7.

Davis, W.W., Stout, T.R. 1971. Disc Plate Method of Microbiological Assay. Journal microbiology.22(4):659-665.

Diassanti, A. 2011. Uji Ekstrak Etanol Daun Mengkudu (Morinda citrifolia) sebagai Antimikroba terhadap Methicillin Resistant Staphylococcus aureus (MRSA) Secara In Vitro [Skripsi]. Fakultas Matematika dan
Ilmu Pengetahuan Alam, Universitas Brawiijaya, Malang.

Harborne, J.B. 1987. Metode Fitokimia. Edisi II. ITB press, Bandung.

Hermansah, A., Harlia., Zahara, T. A. 2015. Skrinning Fitokimia dan Uji Aktivitas Antioksidan Ekstrak Kulit Batang Laban (Vitex Pubescens Vahl). Jurnal Kimia Khatulistiwa. 4 (2) : 69-70.

Khopkar, S.M. 2008. Konsep Dasar Kimia Analitik. UI Press, Jakarta.

Markham, K.R. 1998. Cara Mengidentifikasi Flavonoid. ITB Press, Bandung.

Mujipradhana, V., Defny, W., Edi, S. 2018. Aktivitas Antimikroba dari Ekstrak ascidian herdmania momuspada Mikroba Patogen Manusia. Jurnal Pharmacon.7(3).

Pelczar, M. J., Chan, E. C. S., 1988. DasarDasar Mikrobiologi. UI Press, Jakarta.

Radji, M. 2011. Bukui Ajar Mikrobiologi Panduan Mahasiswa Farmasi dan Kedokteran. Penerbit Buku Kedokteran EGC, Jakarta.

Rukmana, R. 2010. Mengkudu Budi Daya dan Prospek Agribisnis. Kanisius, Yogyakarta.

Saifudin, Aziz. 2014. Senyawa Alam Metabolit Sekunder Teori, Konsep dan Teknik Pemurnian. Budi Utama, Yogyakarta. 
Sastromidjojo, H. 1991. Kromatografi. Liberty. Yogyakarta.

Schlegel, H. G. 1994. Mikrobiologi Edisi Keenam. UGM Press, Yogyakarta.

Sitepu., Josua. 2012. Perbandingan Efektifitas Daya Hambat terhadap Staphylococcus Aureus dari Berbagai Jenis Ekstrak Buah Mengkudu (Morinda Citrofolia L.) (In vitro) [Skripsi]. Fakultas Matematika dan Ilmu Pengetahuan Alam, Universitas Sumatera Utara, Medan.

Voight, R. 1994. Buku Pelajaran Teknologi Farmasi. UGM Press, Yogyakarta.

Widiana, R., Gustiana, I., Harsinta, N. 2011. Daya Hambat Ekstrak Daun Mengkudu (Morinda citrifolia L.) Terhadap Pertumbuhan Bakteri Penyebab Diare. Jurnal Saintek. 3(1) : 60-64.

Wijayati, B.A., Citraningtyas, G., Wehantouw, F. 2014. Potensi Ekstrak Etanol Tangkai Daun Talas (Colocasia Esculenta L.) Sebagai Alternatif Obat Luka Pada Kulit Kelinci, Jurnal Pharmacon 3(3). 